İntrasitoplazmik sperm enjeksiyonu uygulanan 39 yaş ve üzeri infertil kadınlarda prognostik faktörlerin gebelik başarısına etkileri

\title{
The effects of prognostic factors on pregnancy success among women 39 years or older having intracytoplasmic sperm injection
}

\author{
Sultan Seda Doğan, Müge Kovalı, Ömer Erbil Doğan, Bülent Gülekli
}

Dokuz Eylül Üniversitesi Tıp Fakültesi Hastanesi, Tüp Bebek Merkezi, İzmir, Türkiye

\begin{abstract}
Özet
Amaç: Bu çalışmada 39 yaş ve üzeri infertil kadın hastalarda yaşın, prognostik faktörler ile üreme potansiyeli üzerindeki sonuçlarının değerlendirilmesi amaçlandi.

Gereç ve Yöntemler: İleri yaşta ( $\geq 39$ yll) 107 infertil kadın hasta retrospektif olarak değerlendirildi. Hastaların insan koryonik gonadotropin (hCG) uygulanan günde ölçülen endometrium kalınlı̆̆ı, toplam kullanılan gonadotropin dozu, stimülasyon süreleri, 3. gün bazal follikül stimüle edici hormon $(\mathrm{FSH})$ ile bazal estradiol $\left(\mathrm{E}_{2}\right)$ düzeyleri, toplanan oosit ile fertilize oosit saylları ve transfer edilen embriyo saylları kaydedildi. Bu parametrelerin gebelik başarısı üzerine etkileri değerlendirildi. Hastalar 39 yaş (n=47), 40-41 yaş (n=37) ve 42 ve üzeri yaş (n=23) olmak üzere üç yaş grubu karşılaştırıldı.

Bulgular: Canlı doğum oranı 39 yaş grubunda \%23,2 ve 40-41 yaş grubunda \%14,7 olarak gözlendi. Kırk iki ve üzeri yaş grubunda ise canlı doğum görülmedi. Bu çalışmanın sonuçları yaşın, toplanan oosit ve fertilize oosit sayısının gebelik gelişimi üzerine etkisinin olduğunu gösterdi.

Sonuç: Gebelik oranı 39 yaşından sonra hızlı bir şekilde düşmektedir; intrasitoplazmik sperm enjeksiyonu sonrası, hastalarda 39 yaşından itibaren gebelik başarısı 3 yıl sonra 9 kat azalmıştır. İleri maternal yaşın, gebelik ve canlı doğum oranları üzerindeki olumsuz etkisi klinik çalışmamızda da gözlenmiştir. J Turk Soc Obstet Gynecol 2014;2:78-83
\end{abstract}

Anahtar Kelimeler: Kadın, yaş, gebelik oranı

\begin{abstract}
Objective: The objective of this study is to investigate the effect of age on the prognostic factors and fertilization potential of infertile women who are 39 years or older.

Material and Methods: 107 patients with advanced maternal age ( $\geq 39$ years) were included in this retrospective study. The endometrial thickness on the day of human chorionic gonadotropin (hCG), total dose of gonadotropin used, duration of stimulation, levels of day-3 basal follicule stimulating hormone (FSH) and basal estradiol $\left(\mathrm{E}_{2}\right)$, number of retrieved oocytes and fertilized oocytes, and number of embryos transferred were recorded. These parameters were used to evaluate their effects on the success of pregnancy. Patients were categorized into three age groups: 39 years old ( $n=47)$, 40-41 years old ( $n=37$ ), and $\geq 42$ years old $(n=23)$ and age groups were compared.

Results: The rate of live birth was \%23.2 in 39 years and \% 14.7 in $40-41$ years. No live birth in 42 years or older patients was recorded. The results revealed that that the age, number of retrieved oocytes and fertilized oocytes predict the success rate of pregnancy.

Conclusion: Pregnancy rate dramatically decreased after the age of 39; the success of pregnancy after the intracytoplasmic sperm injection decreases 9 times, three years later starting age of 39. The negative effect of advanced maternal age on pregnancy and live birth rates was observed in our clinical study, as well. J Turk Soc Obstet Gynecol 2014;2:78-83
\end{abstract}

Key Words: Women, age, pregnancy rate 


\section{Giriş}

Kadın yaşı üremeye yardımcı siklusların sonucunu etkileyen en önemli değişkendir(1). Yardımla üreme sikluslarında siklus iptal oranlarının yüksek oluşu, düşük klinik gebelik ve implantasyon oranları, abortus ve anöploidi oranlarının artışı ile azalmış canlı doğum oranları ilerleyen kadın yaşı ile ilişkilendirilmiştir(2). Kadınlarda doğurganlık 30 yaşından sonra azalır; bu düşüş 35 ve 40 yaşları arasında hızlanır ve 45 yaşında neredeyse sıfıra yaklaşır(3). Yaşı 35 üzerinde olup infertilite konusunda yardım arayışı içinde olan kadınların sayısındaki artış son yıllarda dikkati çekmektedir. Otuz beş yaşın üzerindeki kadınlarda yardımcı üreme tekniklerindeki başarı şansı azalmaya başlarken 40 yaşla birlikte bebek sahibi olma şansının daha belirgin düştügü görülmüştür(4,5). Kırk yaş ve üzeri kadınlarda yıldan yıla intrasitoplazmik sperm enjeksiyonu (ICSI) sonrası sonuçların değerlendirildiği çalışmalar mevcuttur(6,7). Otuzlu yaşların bitimi ile 40'lı yaşlara geçişi göstermek amacı ile yapılan çalışmamızda mikroenjeksiyon yöntemi sonrası 39 yaş ve üzeri infertil kadınlarda, yaşlanmayla birlikte diğer prognostik faktörlerin üreme potansiyeli üzerindeki sonuçları incelenmiştir.

\section{Gereç ve Yöntemler}

Bu çalışmada Ocak 2004 ile Aralık 2012 tarihleri arasında Kadın Hastalıkları ve Doğum Anabilim Dalı, Üremeye Yardımcı Tedavi Merkezi'ne çocuk sahibi olamama şikayeti ile başvuran, sadece ileri yaş ( $\geq 39)$ infertilite tanısı konan ve ICSI uygulanan 107 kadın hasta retrospektif olarak değerlendirildi. Erkek infertilitesi nedeniyle IVF/ICSI yapılan hastalar çalışmaya alınmadı. Yüz yedi hastanın 94'üne (\%87) embriyo transfer (ET) işlemi yapıldı. Çalışmaya katılan hastaların insan koryonik gonadotropin (hCG) uygulandığ 1 günde ölçülen endometrium kalınlıkları, toplam kullanılan gonadotropin dozu, stimülasyon süreleri, 3. gün bazal follikül stimüle edici hormon (FSH) ile bazal estradiol $\left(\mathrm{E}_{2}\right)$ düzeyleri, toplanan oosit ile döllenen oosit sayıları ve hasta başına transfer edilen embriyo sayıları (TE) kaydedildi. Hastalar 39 yaş $(n=47), 40-41$ yaş $(n=37)$ ve 42 yaş ve üzeri $(n=23)$ olacak şekilde üç yaş grubuna ayrıldı. Gruplar arasındaki ilişki istatistiksel olarak değerlendirildi.

\section{Semen Analizi}

Tüm örneklere makroskopik bakı yapıldıktan sonra mikroskopik değerlendirme ile sperm sayısı ve motilitesi saptand. Sperm konsantrasyonu ve toplam motil sperm yüzdesi DSÖ (Dünya Sağllk Örgütü, 2010) kriterlerine göre belirlendi(8). Semen hazırlığı için swim-up ve gradient yöntemleri uygulandı.

\section{Ovaryan Stimülasyon, Oositlerin Toplanması ve Oosit Hazırlığ}

Çalışmaya katılan 107 hastanın stimülasyon öncesi 3. gün bazal FSH ile bazal $\mathrm{E}_{2}$ düzeylerine bakıldı. Gerekli görülen hastalara GnRH anoloğu (Lucrin; Abbot, Türkiye/
Suprefact; Sanofi Aventis, Türkiye) ile bir önceki siklusun luteal fazının ortasından başlayarak uzun protokol ile hipofizer down regülasyon yapıldı. Optimum down regülasyon sağladıktan sonra bireyselleştirilmiş dozlarda rekombinant FSH (Gonal-F, Serono, Türkiye/Puregon; Organon, Türkiye) veya Human menopozal gonadotropin (Menogon; Erkim, Türkiye/Menopur; Erkim, Türkiye) ile indüksiyon başlandı. Analog kullanılmayan hastalara gonadotropin tedavisi başladıktan 5-6 gün sonra $\mathrm{GnRH}$ antagonist (Orgalutron; Organon, Türkiye/Cetrotide; Serona, Türkiye) tedavisi eklenerek eksojen gonadotropin uyarısına devam edildi. Folliküler büyüme düzenli olarak ultrasonagrafik ölçümlerle izlendi. En az iki follikül çapı $18 \mathrm{~mm}$ olunca 10,000 IU hCG (Pregnyl, Organon, Türkiye veya Ovitrelle, Sereno, Türkiye) uygulandı. hCG'nin uygulandığı günde, ultrasonografi eşliğinde endometriyal kalınlık ölçüldü. Oosit toplama işlemi hCG yapıldıktan 36 saat sonra gerçekleştirildi. Hastalara intravenöz sedasyon uygulandı ve transvaginal ultrasonografi (USG) eşliğinde oositler aspire edildi.

\section{Oositlerin Enjeksiyonu}

Oosit toplama işlemi bittikten sonra toplanan oositler, bir gün önce hazırlanan medyumlu petri kabına aktarıldı ve burada 2-4 saat inkübe edildi. Folliküllerden çalışma için elde edilen oositler ICSI işlemi öncesi mekanik ve kimyasal olarak denüde edildikten sonra invert mikroskopla morfolojik olarak nükleer matürasyonları değerlendirildi. Nükleer matürasyonlarına göre matür (metafaz II), immatür (metafaz I veya germinal vezikül) ve dejenere oositler ayrıldı. Denüde edilen toplam 588 Metafaz II oosite mikroenjeksiyon işlemi yapıldı.

\section{Fertilizasyon ve Embriyo Gelişimi}

Fertilizasyon, ICSI işleminden 16-20 saat sonra iki ayrı pronukleusun görülmesi ile tespit edildi. Klivaj 25 saat sonra değerlendirildi. Embriyo transferi mikroenjeksiyon işleminden yaklaşık 48-72 saat sonra yapıldı. Embriyo kalitesi; hücre sayısı, simetri, blastomerlerin şekli, perivitellin aralıktaki sitoplazmik fragmantasyonların büyüklüğü ve klivaj oranı dahil edilerek morfolojik özelliklere dayanarak modifiye Veeck kıstasları kullanılarak hesaplandı(9). Transabdominal ultrasonografi (USG) rehberliğinde transfer kateterinin (Cook) ucu fundusa dokunmadan yaklaşık 0,5$1 \mathrm{~cm}$ altındayken orta kaviteye embriyo transferi yapıldı. Luteal faz desteği doğal progesteron (Progestan kapsül, 100 mg, Koçak, Türkiye) 600 mg/gün, intravajinal uygulama ile sağlandı. Embriyo transferi sonrası 14. günde serum $\beta$-hCG ölçümü $>25 \mathrm{mIU} / \mathrm{ml}$ ise biyokimyasal gebelik ve embriyo transferinden üç hafta sonra transvajinal USG'de fetal kardiak aktivitenin görülmesi ile klinik gebelik tanındı.

\section{İstatistiksel Analizler}

Veriler Kruskal-Wallis H testi, iki ortalama arasındaki farkın önemlilik testi ve iki oran arasındaki farkın önemlilik testleri kullanılarak analiz edildi $(\mathrm{p}<0,05$ değeri anlamlık seviyesi 
olarak kabul edildi). Sonuçlar ortalama \pm standart sapma (SD) olarak ifade edildi. İstatistiksel analizler SPSS 16.0 paket programı kullanılarak gerçekleştirildi.

\section{Bulgular}

Yüz yedi hastaya ait siklus sonuçları Tablo l'de verilmiştir. ICSI yapılan 107 hastanın 13'üne fertilizasyon olmaması ve embriyoların canlılıklarını devam ettirememesi üzerine transfer işlemi gerçekleştirilememiştir. Altısı biyokimyasal olmak üzere toplam 29 hastada gebelik elde edildi. Gebelik oluşan $(n=29)$ ve gebelik oluşmayan ( $n=65)$ grup karşılaştırıldığında kadın yaşında, toplanan oosit ve fertilize olan oosit sayılarında istatistiksel olarak anlamlı farklılık görüldü $(\mathrm{p}<0,05)$ (Tablo 2). Kadınların yaşları 39 yaş (Grup 1), 40-41 yaş (Grup 2) ve 42 yaş ve üstü (Grup 3) şeklinde gruplandırıldı. Üç yaş grubu karşılaştıııldığında toplanan oosit sayısının, fertilize olan oosit sayısının yaşla birlikte azaldığı ve hasta başına transfer edilen embriyo sayısının istatistiksel olarak farklılık gösterdiği izlendi $(\mathrm{p}<0,05)$ (Tablo 3).

Üç yaş grubu birbirleriyle karşılaştırıldığında ise Grup 1 ve Grup 2 arasında istatistiksel olarak anlamlı bir fark yoktu ( $>0,05)$. Grup 1 ve Grup 2'de toplanan oosit sayısı, fertilize olan oosit sayısı ve hasta başına transfer edilen embriyo sayısı Grup 3 'ten istatistiksel olarak anlamlı derecede fazlaydı $(\mathrm{p}<0,05)$. Stimülasyon süresi, Grup l'de Grup 3'e göre istatistiksel olarak anlamlı şekilde daha uzundu $(\mathrm{p}<0,05)$. Grup 2'de endometriyal kalınlı̆̆ın Grup 3'e göre anlamlı derecede daha kalın olduğu görüldü $(\mathrm{p}<0,05)$ (Tablo 3$)$.

Yaşın ilerlemesiyle embriyo transferi başına klinik gebelik oranının \%34,8'den \%5,8'e kadar düștügü gözlendi. Klinik gebelik oranının yanı sıra, implantasyon oranı ve canlı doğum oranı da yaşla birlikte azaldı (Tablo 4).

\section{Tartışma}

İnsan yaşamının uzaması ve sosyo-ekonomik nedenler kadınlarda çocuk doğurma yaşının geç yaşlara sarkmasına

Tablo 1. Siklus Sonuçları

\begin{tabular}{ll} 
& $\mathrm{n}$ \\
\hline Hasta sayısı & 107 \\
\hline ET olmayan hasta sayısı & 13 \\
\hline Gebelik oluşan hasta sayısı & 29 \\
\hline Transfer edilen embriyo sayısı & 271 \\
& $\%$ \\
\hline Fertilizasyon oranı & $72,9(=429 / 588)$ \\
\hline İmplantasyon oranı & $9,03(=30 / 271)$ \\
\hline Klinik gebelik oranı & $24,4(=23 / 94)$ \\
\hline Canlı doğum oranı & $15,9(=15 / 94)$ \\
\hline Biyokimyasal gebelik oranı & $6,3(=6 / 94)$ \\
\hline Abortus oranı & $34,7(=8 / 23)$
\end{tabular}

sebep olmaktadır. İleri yaşta çocuk sahibi olmak isteyen kadınlarda da infertilite sık görülmektedir. Evlilik yaşı 35-39 olan kadınlarda infertilite oranı \%30 iken, evlilik yaşı 40-45 olan kadınlarda bu oran \%64'tür(2). Artan yaşla birlikte fertilitenin azalmasi; endometriyal reseptivitenin ve oosit kalitesinin azalışı, kromozomal anomalilerin artışı, fertilizasyon veya erken embriyo gelişim kusurları gibi bir dizi faktöre bağlı olabilir(10).

Kadınlarda ilerleyen yaş ile azalan oosit sayısı IVF-ET başarı oranlarını düşürürken, yapılan çalışmalarda siklus başına toplanan oosit sayısının yaşla birlikte gebelik oranlarında düşüşe neden olabileceği görülmüştür(11,12). Bir çalışmada 24 ile 32 yaş arası kadınlarda oosit sayısı yıl başına 1,25 düşüş göstermiştir(11). Sunkara ve ark. yaptıkları çalışmada oosit sayısı ile canlı doğum oranları arasındaki ilişki değerlendirilmiştir(12). Çalışmalarında 18-34 yaş grubu kadınlarda, oosit sayısı yaklaşık 15'e kadar olan sikluslarda doğum oranları yükselirken, oosit sayısı 20'den fazla olduğu durumlarda doğum oranlarında düşüş gözlenmiştir. Aynı çalışmada 38-39 yaş grubu kadınlarda ortalama oosit sayısı 7 olan sikluslarda gözlenen canlı doğum oranı \%21 iken, 40 yaş ve üzeri kadınlarda ortalama oosit sayısı 4 olan sikluslarda gözlenen canlı doğum oranının \%9 olduğu rapor edilmiştir. Çalışmamızda, gebe ve gebe olmayan gruplar karşılaştırıldığında toplanan oosit sayısının gebelik oluşumu üzerine etkisinin istatistiksel olarak anlamlı olduğu görülmüsstür. Literatürle uyumlu olarak; çalışmamızda 39 yaş grubu kadınlarda toplanan oosit sayısı ortalama 7,7 iken bu sikluslarda gözlenen canlı doğum oranı \%23; 42 yaş ve üzeri kadınlarda ortalama toplanan oosit sayısı 4,4; ancak bu sikluslarda canlı doğum olmadığı gözlenmiştir. Toplanan oosit sayısının bizim çalışmamızda 42 yaşından sonra azalması, canlı doğum oranlarında düşüşe neden olabileceğini göstermektedir.

Oosit yaşı ve kalitesi, embriyo implantasyon potansiyelini etkilemektedir. Bu potansiyel özellikle 30'lu yaşlarla beraber yavaş yavaş azalmaya başlar ve 40 yaşından sonra yarı yarıya düşüş gösterir(13). Yapılan çalışmalar, IVF-ET süresince yaşlı ( $40 \geq$ yaş) ve genç ( $\leq 35$ yaş) kadınlar arasında benzer fertilizasyon oranları olduğunu ve yaşlanma sürecinin yaşlı oositlerin döllenme yeteneğini etkilemediğini işaret etmektedir(14). Ancak, düşük implantasyon oranlarının ve yüksek spontan abortus oranlarının yaşlı kadınlardan alınan oositlerden elde edilen embriyolarla yapılan transferler sonucunda olduğu gözlenmiștir(15). Çalıșmamızda da fertilize olan oosit sayısının gebelik başarısını istatistiksel olarak anlamlı şekilde etkilediği görülmüştür $(\mathrm{p}=0,000)$. Yaş grupları karşılaştırıldığında, ilerleyen kadın yaşı ile fertilize olan oosit sayısında ve implantasyon oranındaki anlamlı azalmanın da oosit yaşı ve kalitesi ile ilgili olduğu düşünülmüştür.

Transfer edilen embriyo sayısı devam eden gebelik oranlarını dramatik şekilde etkilemektedir. Kırk yaşındaki kadınlarla yapılan bir çalışmada, sırasıyla 1, 2, 3 ve 4 embriyo transferi 
ile embriyo transferi başına devam eden gebelik oranları sirasiyla \%3, \%7, \%31 ve \%23 olarak verilmekte; sadece dört ve üzeri embriyo transferi yapılan $42-44$ yaşındaki kadın grubunda devam eden gebelikler olduğu belirtilmektedir(7). Sharma ve ark. yaptığı çalışmada, ikiden fazla embriyo transferi ve iki embriyodan daha az embriyo transferi yapılan sikluslar karşılaştırılmış, ikiden fazla embriyo transferi yapılan sikluslarda anlamlı yüksek gebelik şansı olduğu gösterilmiştir(16). Bizim çalışmamızda, 42 yaş ve üzeri kadınlarda hasta başına transfer edilen embriyo sayısının

Tablo 2. Siklus parametrelerinin gebelik oluşan ve oluşmayan gruptaki değerleri

\begin{tabular}{|c|c|c|c|}
\hline Değişken & Gebe $(n=29)$ & Gebe olmayan $(n=65)$ & p değeri \\
\hline Yaş & $39,5 \pm 1,1$ & $40,6 \pm 1,9$ & $0,009 *$ \\
\hline Endometriyal kalınlık (mm) & $9,7 \pm 2,1$ & $9,9 \pm 2,1$ & 0,650 \\
\hline 3. gün bazal FSH (mlIU/ml) & $7,9 \pm 2,1$ & $8,3 \pm 4,0$ & 0,577 \\
\hline 3. gün bazal $E_{2}(p g / m l)$ & $58,2 \pm 63,5$ & $64,2 \pm 54,7$ & 0,642 \\
\hline Toplam gonodotropin dozu & $4718,3 \pm 1958,5$ & $4821,1 \pm 2226,1$ & 0,831 \\
\hline Stimülasyon süresi (gün) & $11,6 \pm 3,3$ & $11,4 \pm 3,3$ & 0,870 \\
\hline Toplanan oosit sayısı (ort) & $10,1 \pm 6,1$ & $6.3 \pm 4,4$ & $0,001^{*}$ \\
\hline Fertilize oosit sayısı & $6,9 \pm 4,9$ & $3,5 \pm 2,7$ & $0,000^{*}$ \\
\hline$\left({ }^{*}\right.$ anlamlı $\left.\mathrm{p}<0,05\right)$ & & & \\
\hline
\end{tabular}

Tablo 3. Yaş gruplarına göre parametrelerin değişimi

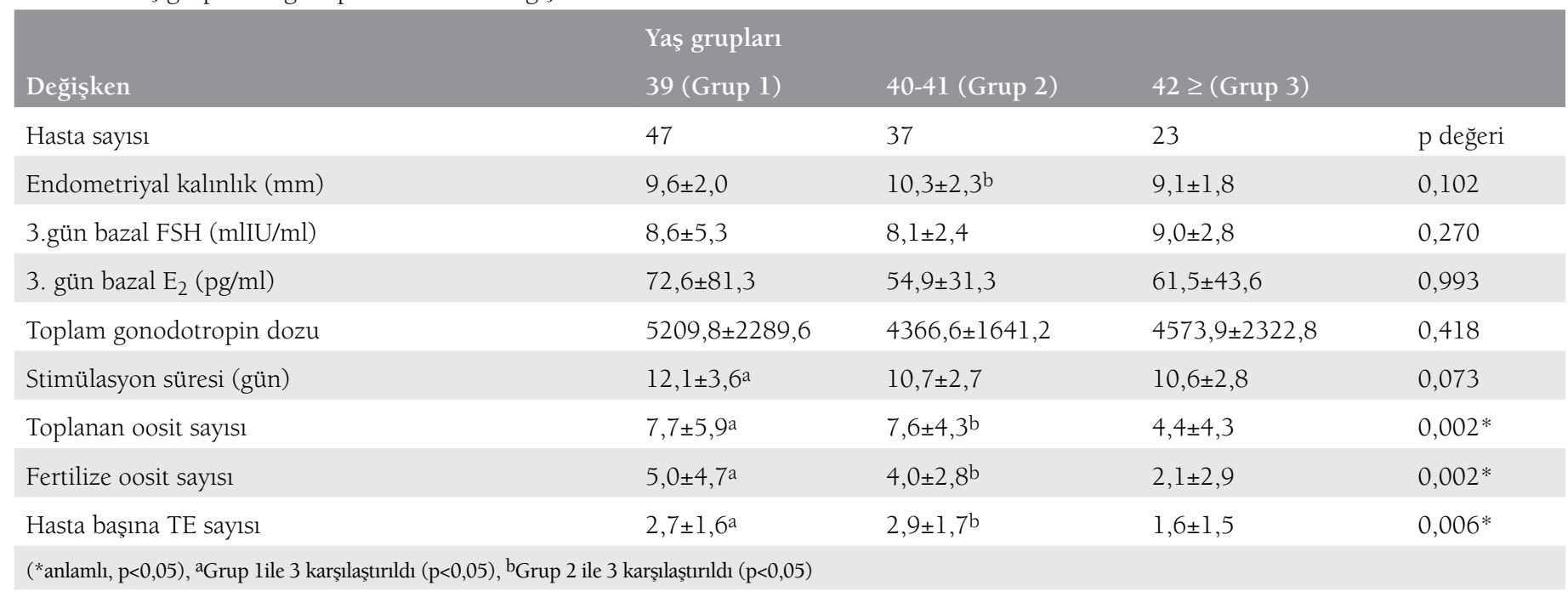

Tablo 4. Yaş gruplarına göre ICSI sonuçları

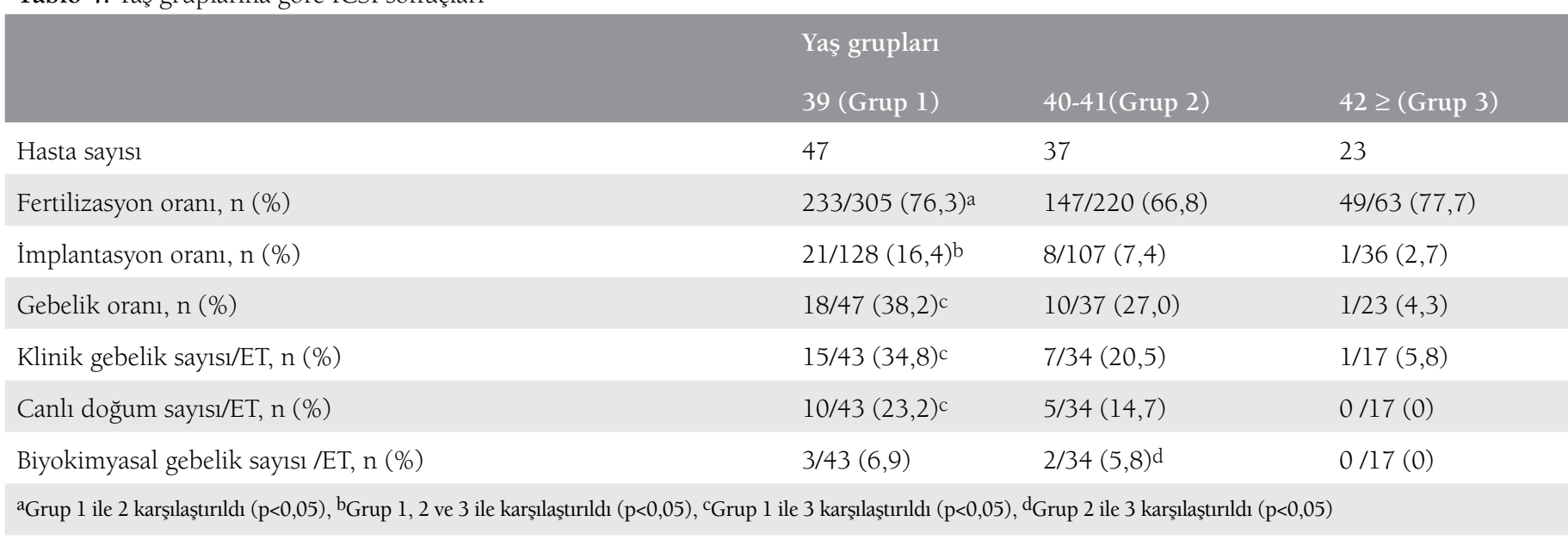


azlığı, elde edilen oosit sayısı ile doğrudan ilişkilidir. Grup 3'de transfer edilen embriyo sayısının diğer iki gruba kıyasla anlamlı az olması; buna bağlı olarak klinik gebelik oranı ile canlı doğum oranındaki düşüş de literatürle uyumlu olarak dikkati çekmektedir.

Kadınlardaki FSH ölçümünün, overlerin ovulasyon indüksiyonuna vereceği cevabın değerlendirilmesinde etkili, gebelik elde etme oranlaryyla iyi uyum gösteren, over rezervini de dolaylı olarak ortaya koyan test olduğu kabul edilmektedir(10). Yaşlanma sırasında FSH ve LH seviyelerinin artması fertilitenin azalması ile ilişkilidir(10). Kırk yaş ve üzeri 107 hasta ile yapılan bir çalışmada, 3 . gün FSH değerinin 15 IU/l'ten yüksek olduğu durumlarda gebelik oranlarında anlamlı bir azalma olduğu ve 25 IU/l'ten yüksek olduğu durumlarda gebeliğin nadir olduğu bildirilmiștir(17). Gebelik oranlarındaki bu azalma ovaryan rezervinin azalması ile de ilişkilidir. Bu hastalarda az sayıda follikül geliștiği, daha az sayıda oosit toplandığı ve dolayısıyla az sayıda embriyo elde edildiği de belirtilmiștir. Toner ve ark. çalıșmalarında hem bazal FSH'nın hem de yaş faktörünün IVF performansında etkili olduğunu belirtmişlerdir(18). Yapılan diğer çalışmalarda bazal FSH'sı 0-10 IU/1 ve $10 \mathrm{IU} / 1$ 'den yüksek olan hastalar iki grupta değerlendirilmiş ve bazal FSH'sı 0-10 IU/1 olan kadınlarda gebelik şansının daha yüksek olduğu bildirilmiștir(19,20). Bizim çalışmamızda, gebe $(7,9 \pm 2,1)$ ve gebe olmayan $(8,3 \pm 4,0)$ grupların bazal FSH değerleri karşılaştırıldığında bu değerin gebelik oluşumunu istatistiksel olarak anlamlı etkilemediği görülmüştür. Bazal $\mathrm{E}_{2}$ hormonu da IVF tedavisinde overlerin tedaviye yanıtını erken tahmin etme aşamasında ölçülmektedir. Frattarelli ve ark. 2476 hasta ile yaptıkları çalışmada bazal $\mathrm{E}_{2}$ değeri $20 \mathrm{pg} / \mathrm{ml}$ 'den düşük ya da $80 \mathrm{pg} / \mathrm{ml}$ 'den yüksek olan kadınlardan elde edilen oosit sayısında ve bu kadınların gebelik oranlarında anlamlı azalma olduğunu belirtmişlerdir(21). Çalışmamızda, bazal $E_{2}$ değeri $20 \mathrm{pg} / \mathrm{ml}$ 'den düşük olan kadınlardan ikisinde biyokimyasal gebelik ve $80 \mathrm{pg} / \mathrm{ml}$ 'den yüksek olan kadınlardan üçünde ise klinik gebelik oluşmuştur. Bazal $\mathrm{E}_{2}$ değerinin gebelik üzerine etkisinin anlamlı olmadığı ve üç yaş grubu karşılaştırıldığında da anlamlı bir değişim göstermediği kaydedilmiștir (Tablo 2).

Yaşla birlikte hormonal değişiklikler endometrium fonksiyonlarını etkilemektedir; böylece endometriumun embriyonun implantasyonunu ve büyümesini destekleme yeteneği de azalmaktadır(22). Endometrium kalınlığının gebeliğin oluşması ve implantasyon için önemli olduğu bilinmekle birlikte, IVF tedavisine alınan hastalardaki klinik önemi ile ilgili farklı görüşler bildirilmiştir. Rashidi ve ark. çalışmalarında, hCG gününde ölçülen endometrium kalınlığının gebelik oluşumunda prognostik bir değerinin olmadığını; ancak endometriyal kalınlığın 9 mm'den az ve 12 mm'den fazla olduğu durumlarda gebelik oranlarının azaldığını bildirmişlerdir(23). İki yüz hasta ile yapılan bir başka çalışmada hCG gününde ölçülen endometriyal kalınlık $9 \mathrm{~mm}-13 \mathrm{~mm}$ arası ve $14 \mathrm{~mm}$ 'den fazla olmak üzere iki grup olarak karşılaştırılmış ancak anlamlı bir fark bulunmamıştır; fakat artan endometriyal kalınlıkla yüksek biyokimyasal gebelik oranları olduğu belirtilmiştir(24). Bizim yaptığımız çalışma ise, hCG gününde ölçülen endometrium kalınlığının çalışma popülasyonumuzda gebelik oluşumu üzerine etkisinin olmadığını ortaya çıkarmıştır. Yaş grupları karşılaştırıldığında; Grup 2'de ölçülen endometriyal kalınlığın ve biyokimyasal gebelik oranının Grup 3'e göre istatistiksel olarak anlamlı fazla olması; artan endometriyal kalınlıkla yüksek biyokimyasal gebelik oranı ile literatürle uyumluluk göstermektedir.

Martin ve ark. 555 adet siklusla yaptıkları çalışmada gonadotropin stimülasyon süresinin ve dozunun gebelik sonuçlarını etkilemediğini rapor etmişlerdir(25). Bizim çalıșmamızda, toplam kullanılan gonodotropin dozunun ve stimülasyon süresinin gebelik başarısını etkilemediği ancak yaş grupları arasında Grup l'de Grup 3'e göre stimülasyon süresinin istatistiksel olarak anlamlı uzun olduğu gözlenmiştir. Bununla birlikte Grup l'de en yüksek canlı doğum oranı görülmüştür. Altı yüz doksan dokuz adet siklusla yapılan bir analizde ise gonadotropin stimülasyon süresinin uzun olmasının, canlı doğum oranlarındaki azalma ile ilișkili olabileceği belirtilmiștir(26). Bu çalışmanın aksine, stimülasyon süresinin uzamasıyla canlı doğum oranlarında azalma görülmemiştir. Bunun da oosit kalitesi ve transfer edilen embriyo sayısı ile ilgili olduğu düşünülmüştür.

Yedi yüz otuz altı ICSI siklusu ile yapılan bir çalışmada, 40-43 yaş arası kadınlarda siklus başına canlı doğum oranı $\% 9$ olarak rapor edilmiştir(27). 2005'te yayınlanan bir çalışmada 40 yaş ve üzeri 1263 kadın hastada, 40, 41, 42, 43 yaşları sırasıyla $\% 13, \% 9,7, \% 9,2, \% 7,6$ canlı doğum oranları bildirilmiştir. Ancak 43 yaş ve sonrasında canlı doğum oranının \%3'ten az olduğu ve ayrıca 46 yaş ve sonrasında canlı doğum olmadığı belirtilmiştir(6). 2010'da yayınlanan bir başka çalışmada da 40 ve 41 yaşta canlı doğum oranı sırasıyla \%21 ve \%7, $42-44$ yaş arası \%3-\%4 ve 45 yaş ve üzerinde canlı doğum olmadığı bildirilmiştir(7). Çalışmamızda ise 39 yaş ve $40-41$ yaş gruplarında, transfer başına elde edilen canlı doğum oranları sırasıyla \%23,2 ve \%14,7 olarak bulunmuștur. Kırk iki yaş ve üzeri grupta canlı doğum olmamıştır.

Anti-Müllerian hormon (AMH) değerinin over stimülasyon sonrası oosit verimliliği ile ilişkili olduğu gösterilmiştir(28). AMH değerlerinin düzenli bir şekilde bakılamadığı gerekçesiyle çalışmamızda değerlendirilememiştir. Yapılacak bir başka çalıșmada bu değerlerin eklenmesi, elde edilen oosit sayısını ve canlı doğum oranlarını doğrulama açısından yararlı olabilir.

\section{Sonuç}

Verilerimiz bu yaş grupları için endometrium kalınlığının, 3 . gün bazal FSH ile bazal $E_{2}$ değerlerinin, toplam gonadotropin dozunun, stimülasyon süresinin gebelik gelişimi üzerine etkisinin olmadığını göstermiştir. Ancak yaş faktörünün; 
bununla birlikte toplanan oosit ve fertilize olan oosit sayısının gebe kalma olasılığını olumsuz etkilediği görülmektedir. Toplanan oosit sayısı, fertilize oosit sayısı, hasta başına transfer edilen embriyo sayısı ve gebelik oranlarının yaş grupları arasındaki istatistiksel olarak anlamlı farklılığı ileri kadın yaşının kötü ICSI cevabı olarak yorumlanmıştır.

Üreme tedavisinde infertil çiftler için yalnızca yaş tek belirleyici faktör olmamalıdır; yaşlanan oositlerin kalitesinde bireysel varyasyonlar farklı sonuçlar üretebilir(29). Bu yaş grubundaki hastaların, kadın üreme sistemindeki yaşlanmanın etkileri hakkında bilgilendirilmesi yararlı olacaktır. Ülkemizdeki yasal durum çiftlere; sadece kendi gametlerini kullanma şansı sunduğu için ileri maternal yaşta gebelik isteyen kadınlara, her kliniğin kendi gerçekçi rakamlarını vermeleri gerektiği inancindayı.

\section{Kaynaklar}

1. Templeton A, Morris JK, Parslow W. Factors that affect outcome of in-vitro fertilization treatment. Lancet 1996;348(9039):1402-6.

2. Krey L, Liu H, Zhang J, Grifo J. Fertility and maternal age. Ann NY Acad Sci 2001;943(1):26-33.

3. Menken J, Trussel J, Larsen U. Age and infertility. Science 1986;233:389-94

4. Spandorfer SD, Avrech OM, Colombero LT, Palermo GD, Rosenwaks Z. Effect of parental age on fertilization and pregnancy characteristics in couples treated by intracytoplasmic sperm injection. Hum Reprod 1998;13(2):334-8.

5. Gomes LM, Canha Ados S, Dzik A, Novo NF, Juliano Y, Dos Santos SI, et al. The age as a predictive factor in in vitro fertilization cycles. Rev Bras Gynecol Obstet 2009;31(5):230-4.

6. Adonakis G, Camus M, Joris H, Vandervorst M, Van Steirteghem A, Devroey P. The role of the number of replaced embryos on intracytoplasmic sperm injection outcome in women over the age of 40. Hum Reprod 1997;12(11):2542-45.

7. Yarali H, Bozdag G, Polat M, Esinler I, Tiras B. Intracytoplasmic sperm injection outcome of women over 39: an analysis of 668 cycles. Arch Gynecol Obstet 2010;281(2):349-54.

8. Cooper TG, Noonan E, Eckardstein S, Auger J, Gordon Baker HW, Behre HM, et al. World Health Organization reference values for human semen characteristics. Hum Reprod Update 2010;16(3):231-45.

9. Veeck LL. Preembryo grading. Atlas of the Human Oocyte and Early Conceptus. 2nd ed. Baltimore: Wiliams and Wilkins 1991.p.121-49.

10. Szamatowicz M, Grochowski D. Fertility and infertility in aging women. Gynecol Endocrinol 1998;12(6):407-13.

11. Stolwijk AM, Zielhuis GA, Sauer MV, Hamilton CJ, Paulson, RJ. The impact of the women's age on the success of standard and donor in vitro fertilization. Fertil Steril 1997;67(4):702-10.

12. Sunkara S, Rittenberg V, Raine-Fenning N, Bhattacharya S, Zamora J, Coomarasamy A. Association between the number of eggs and live birth in IVF treatment: an analysis of 400135 treatment cycles. Hum Reprod 2011;26(7):1768-74.
13. Hull MGR, Fleming CF, Hughes AO, McDermott A. The age-related decline in female fecundity: a quantitative controlled study of implanting capacity and survival of individual embryos after in vitro fertilization. Fertil Steril 1996;65(4):783-90.

14. Lim AS, Tsakok MF. Age-related decline in fertility: a link to degenerative oocytes? Fertil Steril 1997;68(2):265-71.

15. Fitzgerald C, Zimon AE, Jonesa EE. Aging and reproductive potential in women. Yale J Biol Med. 1998;71(5):367-81.

16. Sharma V, Allgar V, Rajkhowa M. Factors influencing the cumulative conception rate and discontinuation of in vitro fertilization treatment for infertility. Fertil Steril 2002;78(1):40-6.

17. Scott RT, Toner JP, Muasher SJ, Oehninger S, Robinson S, Rosenwaks Z. Follicle-stimulating hormone levels on cycle day 3 are predictive of in vitro fertilization outcome. Fertil Steril 1989;51(4):651-4.

18. Toner JP, Philput CB, Jones GS, Muasher SJ. Basal follicle-stimulating hormone level is a better predictor of in vitro fertilization performance than age. Fertil Steril 1991;55(4):784-91.

19. Ottosen LD, Kesmodel U, Hindkjaer J, Ingerslev HJ. Pregnancy prediction models and eSET criteria for IVF patients-do we need more information? J Assist Reprod Genet 2007;24(1):29-36.

20. Sabatini L, Zosmer A, Hennessy EM, Tozer A, Al-Shawaf T. Relevance of basal serum FSH to IVF outcome varies with patient age. Reprod Biomed Online 2008;17(1):10-9.

21. Frattarelli J, Bergh P, Drews M, Sharara F, Scott T. Evaluation of basal estradiol levels in assisted reproductive technology cycles. Fertil Steril 2004;74(3):518-24

22. Momeni M, Rahbar MH, Kovanci E. A meta-analysis of the relationship between endometrial thickness and outcome of in vitro fertilization cycles. J Hum Reprod 2011;4(3):130-7.

23. Rashidi B, Sadeghi M, Jafarabadi M, Nejad E. Relationships between pregnancy rates following in vitrofertilization or intracytoplasmic sperm injection and endometrial thickness and pattern. Eur J Obstet Gynecol Reprod Biol 2005;120(2):179-84.

24. Dickey RP, Olar TT, Taylor SN, Rye PH. Endometrial pattern and thickness associated with pregnancy outcome after assisted reproduction technologies. Hum Reprod 1992;7(3):418-21.

25. Martin JR, Mahutte NG, Arici A, Sakkas D. Impact of duration and dose of gonadotrophins on IVF outcomes. Reprod Biomed Online 2006;13(5):645-50.

26. Chuang M, Zapantis A, Taylor M, Jindal SK, Neal-Perry GS, Lieman $\mathrm{HJ}$, et al. Prolonged gonadotropin stimulation is associated with decreased ART success. J Assist Reprod Genet 2010;27(12):711-17.

27. Grimbizis G, Vandervorst M, Camus M, Tournaye H, Van Steirteghem A, Devroey P. Intracytoplasmic sperm injection, results in women older than 39, according to age and the number of embryos replaced in selective or non-selective transfers. Hum Reprod 1998;13(4):884-89.

28. Khader A, M Lloyd S, Mc Connachie A, Fleming R, Grisendi V, La Marca A, et al. External validation of anti-Müllerian hormone based prediction of live birth in assisted conception. J Ovarian Res 2013;6(1):3.

29. Cetinkaya MB, Siano LJ, Benadiva C, Sakkas D, Patrizio P. Reproductive outcome of women 43 years and beyond undergoing ART treatment with their own oocytes in two Connecticut university programs. J Assist Reprod Genet 2013;30(5):673-8. 